\title{
Trachyspic Acid, a New Metabolite Produced by Talaromyces trachyspermus, that Inhibits Tumor Cell Heparanase: Taxonomy of the Producing Strain, Fermentation, Isolation, Structural Elucidation, and Biological Activity
}

\author{
Hideyuki Shiozawa, Masaaki Takahashi ${ }^{a}$, Toshio Takatsu, Takeshi Kinoshita ${ }^{\mathrm{b}}$, \\ Kazuhiko Tanzawa ${ }^{a}$, Tsuyoshi Hosoya ${ }^{c}$, Kouhei Furuya ${ }^{c}$, \\ and Shuji TAKaHASHI
}

\author{
Biomedical Research Laboratories, ${ }^{\text {a }}$ Biological Research Laboratories, \\ ${ }^{b}$ Analytical and Metabolic Research Laboratories, Sankyo Co., Ltd., \\ 2-58 Hiromachi 1-chome, Shinagawa-ku, Tokyo 140, Japan \\ 'Tsukuba Research Laboratories, Sankyo Co., Ltd., \\ 33 Miyukigaoka, Tsukuba-shi, Ibaraki 305, Japan \\ Kazuo Furihata ${ }^{d}$ and Haruo Seto ${ }^{e}$ \\ ${ }^{d}$ Division of Agriculture and Agricultural Life Sciences, \\ e Institute of Molecular and Cellular Biosciences, The University of Tokyo, \\ Bunkyo-ku, Tokyo 113, Japan
}

(Received for publication December 13, 1994)

\begin{abstract}
Trachyspic acid, a new metabolite that inhibited heparanase, was isolated from the culture broth of Talaromyces trachyspermus SANK 12191. Its structure was deduced from NMR spectral analyses and chemical reactions as a tricarboxylic acid derivative containing a spiroketal. The $\mathrm{IC}_{50}$ value of trachyspic acid against heparanase was $36 \mu \mathrm{M}$.
\end{abstract}

Basement membranes are a tissue barrier that tumor cells must penetrate in the process of invasion and metastasis. Therefore, their degradation is an important step in pathogenesis, and extensive efforts have been paid to clarify the role of proteases and glycosidases in this step. ${ }^{1)}$ Among them is heparanase an endo- $\beta$-glucuronidase that was originally identified in murine B16 melanoma. It degrades heparan sulfate (HS), one of the major components of basement membranes. Reportedly, heparanase activities are correlated with the metastatic potential of malignant cells. ${ }^{2,3}$ ) HS also provides a storage site for heparin-binding growth factors, such as basic fibroblast growth factor (bFGF). When HS is degraded by heparanase, bFGF is released from $\mathrm{HS}$, to stimulate endothelial cell proliferation and capillary cell growth. ${ }^{4)}$ It is, therefore, suggested that heparanase participates in both tumor invasion and angiogenesis.

Heparanase is inhibited by heparin, heparin derivatives, and suramin. In fact, they inhibit pulmonary metastasis of B16 melanoma. ${ }^{5 \sim 7)}$ In spite of these studies, little is known to date about the structural requirement of low-molecular-weight heparanase inhibitors. In this sense, studies on the natural compounds that inhibit this glycosidase will be informative.

In the course of our screening for heparanase inhibitors, we found a new metabolite from the culture broth of Talaromyces trachyspermus SANK 12191, and named it trachyspic acid. In this paper, we report the taxonomy of the producing strain, fermentation, isolation, structural elucidation, and some biological characteristics of trachyspic acid.

\section{Experimental}

Heparanase Assay

B16-BL6 was kindly supplied by Dr. FIDLER, Univ. of Texas, M. D. Anderson Cancer Center. HeparinSepharose was purchased from Pharmacia-LKB. Heparan sulfate was purchased from Seikagaku Kogyo, Japan. Heparanase was extracted and partially purified from B16-BL6 melanoma cells using heparin-Sepharose according to the method of NAKAJIMA et al. ${ }^{6)}$ HS was radiolabeled with $\left[{ }^{3} \mathrm{H}\right]$ acetic anhydride. ${ }^{8)}$ The solidphase radiolabeled substrate was prepared based on the method of NAKAJIMA et $a l .{ }^{8)}$ with slight modifications, and was used for the enzyme assay. A suspension of the $\left[{ }^{3} \mathrm{H}\right]$ acetyl $\mathrm{HS}$ immobilized to gel beads was mixed with the partially purified enzyme and incubated in a total volume of $400 \mu \mathrm{l}$ of assay mixture, consisting of $0.2 \mathrm{M}$ sodium acetate ( $\mathrm{pH} 5.0$ ) and $20 \mathrm{~mm}$ D-saccharic acid 1,4-lactone, at $37^{\circ} \mathrm{C}$ for 3 hours with vigorous shaking. The enzyme reaction was terminated by adding $40 \mu \mathrm{l}$ of $50 \%$ trichloroacetic acid. The mixture was then centrifuged at $9,800 \times g$ for 5 minutes, and radioactivity in a $200-\mu \mathrm{l}$ aliquot of the supernatant was determined in a 
scintillation counter.

\section{Taxonomic Studies}

The strain SANK 12191 was isolated from soil collected at Kagoshima Pref., Japan, in April 1989. Taxonomic studies and identification were conducted according to the procedures described by PITT. ${ }^{9)}$ Color hues are described according to the method of KORNERUP and WANSCHER. ${ }^{10)}$

\section{Fermentation}

A slant culture of the strain SANK 12191 was used to inoculate into a $500-\mathrm{ml}$ Erlenmeyer flask containing $100 \mathrm{ml}$ of GPMY medium (glycerol $50 \mathrm{~g}$, fresh potato $50 \mathrm{~g}$, yeast extract $5 \mathrm{~g}$, malt extract $5 \mathrm{~g}$, tap water $1,000 \mathrm{ml}$ ). The flask was shaken on a rotary shaker for 5 days at $26^{\circ} \mathrm{C}$. Two $\mathrm{ml}$ of the seed culture was transferred into respective $500-\mathrm{ml}$ Erlenmeyer flasks containing the same medium described above, and fermentation in 20 flasks was carried out at $26^{\circ} \mathrm{C}$ for 6 days.

\section{Trimethyl Ester (2)}

Trachyspic acid (224 mg) was dissolved in $5 \mathrm{ml}$ of $\mathrm{MeOH}$, followed by addition of excessive diazomethane ether solution. After reaction for 5 minutes at $0^{\circ} \mathrm{C}$, the reaction mixture was concentrated under reduced pressure. The obtained residue was purified with preparative HPLC (Senshu pak ODS H-4251 (Senshu Scientific Co., Ltd.), $10 \times 250 \mathrm{~mm}$, eluent: $\left.75 \% \mathrm{CH}_{3} \mathrm{CN}\right)$, to give $78 \mathrm{mg}$ of 2: $\mathrm{MS}(\mathrm{EI}) \mathrm{m} / z 454\left(\mathrm{M}^{+}\right), 455\left(\mathrm{M}+\mathrm{H}^{+}\right)$, 243 (base peak); IR $\left(\mathrm{CHCl}_{3}\right) \mathrm{cm}^{-1} 1740,1610 ;{ }^{1} \mathrm{H}$ NMR $\left(400 \mathrm{MHz}, \mathrm{DMSO}-d_{6}\right) \delta 2.88\left(1 \mathrm{H}, \mathrm{d}, J=16.9 \mathrm{~Hz}, 2-\mathrm{H}_{\mathrm{a}}\right)$, $2.94\left(1 \mathrm{H}, \mathrm{d}, J=16.9 \mathrm{~Hz}, 2-\mathrm{H}_{\mathrm{b}}\right), 3.82(1 \mathrm{H}, \mathrm{dd}, J=7.3$, $12.5 \mathrm{~Hz}, 4-\mathrm{H}), 2.44(2 \mathrm{H}, \mathrm{m}, 5-\mathrm{H}), 8.48(1 \mathrm{H}, \mathrm{s}, 9-\mathrm{H}), 2.02$ $(2 \mathrm{H}, \mathrm{m}, 10-\mathrm{H}), 1.41(2 \mathrm{H}, \mathrm{m}, 11-\mathrm{H}), 1.24(12 \mathrm{H}, \mathrm{br}$, from 12- to $17-\mathrm{H}), 0.86(3 \mathrm{H}, \mathrm{t}, J=7.0 \mathrm{~Hz}, 18-\mathrm{H}), 3.57(3 \mathrm{H}, \mathrm{s})$, $3.65(3 \mathrm{H}, \mathrm{s}), 3.72(3 \mathrm{H}, \mathrm{s})$.

\section{Reduction of Trachyspic Acid}

Trachyspic acid (290 $\mathrm{mg})$ was dissolved in $15 \mathrm{ml}$ of $\mathrm{MeOH}$, and $300 \mathrm{mg}$ of $10 \% \mathrm{Pd}-\mathrm{C}$ was added to the solution. After reduction under $\mathrm{H}_{2}$ gas atmosphere, the reaction mixture was filtered, to remove the catalyst, followed by concentration under reduced pressure. The obtained residue was applied on a Sephadex LH-20 (Pharmacia) column $(25 \times 200 \mathrm{~mm})$, and the column was developed with a mixture of EtOAc- $\mathrm{CH}_{2} \mathrm{Cl}_{2}-\mathrm{MeOH}$ $(19: 19: 2)$. The obtained material was further purified with preparative HPLC (Senshu pak ODS H-4251, $10 \times 250 \mathrm{~mm}$, eluent: $55 \% \mathrm{CH}_{3} \mathrm{CN}$ containing $0.1 \%$ trifluoroacetic acid), to give $10.5,17.6,68.5$, and $26.8 \mathrm{mg}$ of reduced compounds $\mathbf{3}, \mathbf{4}, \mathbf{5}$, and $\mathbf{6}$, respectively.

3: MS (FAB) $m / z 415\left(\mathrm{M}+\mathrm{H}^{+}\right)$; ${ }^{1} \mathrm{H}$ NMR $(400 \mathrm{MHz}$, CD $\left.{ }_{3} \mathrm{OD}\right) \delta 2.71\left(1 \mathrm{H}, \mathrm{d}, J=16.4 \mathrm{~Hz}, 2-\mathrm{H}_{\mathrm{a}}\right), 3.08(1 \mathrm{H}, \mathrm{d}$, $\left.J=16.4 \mathrm{~Hz}, 2-\mathrm{H}_{\mathrm{b}}\right), 3.01(1 \mathrm{H}, \mathrm{dd}, J=2.8,10.2 \mathrm{~Hz}, 4-\mathrm{H})$, $1.67\left(1 \mathrm{H}, \mathrm{m}, 5-\mathrm{H}_{\mathrm{a}}\right), 2.16\left(1 \mathrm{H}, \mathrm{m}, 5-\mathrm{H}_{\mathrm{b}}\right), 4.46(1 \mathrm{H}, \mathrm{dd}$, $J=5.6,8.3 \mathrm{~Hz}, 6-\mathrm{H}), 8.21(1 \mathrm{H}, \mathrm{s}, 9-\mathrm{H}), 2.10(2 \mathrm{H}, \mathrm{m}$, $10-\mathrm{H}), 1.46(2 \mathrm{H}, \mathrm{m}, 11-\mathrm{H}), 1.29(12 \mathrm{H}, \mathrm{br}$, from $12-$ to
$17-\mathrm{H}), 0.89(3 \mathrm{H}, \mathrm{t}, J=6.7 \mathrm{~Hz}, 18-\mathrm{H})$.

4: MS (FAB) $m / z 417\left(\mathrm{M}+\mathrm{H}^{+}\right) ;{ }^{1} \mathrm{H}$ NMR $(400 \mathrm{MHz}$, $\left.\mathrm{CD}_{3} \mathrm{OD}\right) \delta 2.68\left(1 \mathrm{H}, \mathrm{d}, J=16.5 \mathrm{~Hz}, 2-\mathrm{H}_{\mathrm{a}}\right), 3.07(1 \mathrm{H}, \mathrm{d}$, $\left.J=16.5 \mathrm{~Hz}, 2-\mathrm{H}_{\mathrm{b}}\right), 2.89(1 \mathrm{H}, \mathrm{dd}, J=2.3,10.9 \mathrm{~Hz}, 4-\mathrm{H})$, $1.82\left(1 \mathrm{H}, \mathrm{ddd}, J=2.3,5.1,14.1 \mathrm{~Hz}, 5-\mathrm{H}_{\mathrm{a}}\right), 2.07(1 \mathrm{H}, \mathrm{ddd}$, $\left.J=9.4,10.9,14.1 \mathrm{~Hz}, 5-\mathrm{H}_{\mathrm{b}}\right), 3.87(1 \mathrm{H}, \mathrm{dd}, J=5.1,9.4 \mathrm{~Hz}$, $6-\mathrm{H}), 2.51(1 \mathrm{H}, \mathrm{m}, 8-\mathrm{H}), 3.82(1 \mathrm{H}, \mathrm{dd}, J=7.4,9.3 \mathrm{~Hz}$, $\left.9-\mathrm{H}_{\mathrm{a}}\right), 4.22\left(1 \mathrm{H}, \mathrm{t}, J=8.7 \mathrm{~Hz}, 9-\mathrm{H}_{\mathrm{b}}\right), 1.39\left(1 \mathrm{H}, \mathrm{m}, 10-\mathrm{H}_{\mathrm{a}}\right)$, $1.67\left(1 \mathrm{H}, \mathrm{m}, 10-\mathrm{H}_{\mathrm{b}}\right), 1.29(14 \mathrm{H}$, br, from $11-$ to $17-\mathrm{H})$, $0.90(3 \mathrm{H}, \mathrm{t}, J=6.9 \mathrm{~Hz}, 18-\mathrm{H}) ;{ }^{13} \mathrm{C}$ NMR $(90 \mathrm{MHz}$, DMSO-d $\left.{ }_{6}\right) \delta 174.5(\mathrm{~s}, \mathrm{C}-1), 40.5(\mathrm{t}, \mathrm{C}-2), 74.9(\mathrm{~s}, \mathrm{C}-3)$, 50.4 (d, C-4), 27.4 (t, C-5), 78.4 (d, C-6), 217.1 (s, C-7), 46.0 (d, C-8), 68.7 (t, C-9), 28.0 (t, C-10), 22.0, 26.7, 28.6, $28.7,28.8 \times 2$ and 31.2 (t, from $\mathrm{C}-11$ to $\mathrm{C}-17$ ), 13.9 (q, C-18), 171.3 (s, C-19), 172.8 (s, C-20). The assignment of $\mathrm{C}-1$ and $\mathrm{C}-19$ is interchangeable.

5: $\mathrm{MS}$ (FAB) $m / z 439$ (positive) $\left(\mathrm{M}+\mathrm{Na}^{+}\right), 415$ (negative) $\left(\mathrm{M}-\mathrm{H}^{-}\right)$; The ${ }^{1} \mathrm{H}\left(400 \mathrm{MHz}, \mathrm{CD}_{3} \mathrm{OD}\right)$ and ${ }^{13} \mathrm{C}\left(90 \mathrm{MHz}, \mathrm{CD}_{3} \mathrm{OD}\right) \mathrm{NMR}$ spectral data are summarized in Table 1.

6: MS (FAB) $m / z 415\left(\mathrm{M}+\mathrm{H}^{+}\right) ;{ }^{1} \mathrm{H}$ NMR $(400 \mathrm{MHz}$, $\left.\mathrm{CD}_{3} \mathrm{OD}\right) \delta 2.82\left(1 \mathrm{H}, \mathrm{d}, J=16.7 \mathrm{~Hz}, 2-\mathrm{H}_{\mathrm{a}}\right), 2.96(1 \mathrm{H}, \mathrm{d}$, $\left.J=16.7 \mathrm{~Hz}, 2-\mathrm{H}_{\mathrm{b}}\right), 3.63(1 \mathrm{H}, \mathrm{dd}, J=7.6,12.2 \mathrm{~Hz}, 4-\mathrm{H})$, $2.19\left(1 \mathrm{H}, \mathrm{dd}, J=7.6,13.3 \mathrm{~Hz}, 5-\mathrm{H}_{\mathrm{a}}\right), 2.61(1 \mathrm{H}, \mathrm{t}$, $\left.J=12.7 \mathrm{~Hz}, 5-\mathrm{H}_{\mathrm{b}}\right), 2.51(1 \mathrm{H}, \mathrm{m}, 8-\mathrm{H}), 3.99(1 \mathrm{H}, \mathrm{t}$, $\left.J=9.0 \mathrm{~Hz}, 9-\mathrm{H}_{\mathrm{a}}\right), 4.37\left(1 \mathrm{H}, \mathrm{t}, J=8.8 \mathrm{~Hz}, 9-\mathrm{H}_{\mathrm{b}}\right), 1.42(1 \mathrm{H}$, $\left.\mathrm{m}, 10-\mathrm{H}_{\mathrm{a}}\right), 1.75\left(1 \mathrm{H}, \mathrm{m}, 10-\mathrm{H}_{\mathrm{b}}\right), 1.29(14 \mathrm{H}$, br, from 11 - to $17-\mathrm{H}), 0.90(3 \mathrm{H}, \mathrm{t}, J=6.8 \mathrm{~Hz}, 18-\mathrm{H})$.

\section{Results and Discussion}

Taxonomy of the Strain SANK 12191

The mycological characteristics of the strain SANK 12191 are described below. Colonies on CYA (Czapek Yeast Extract Agar) were $21 \mathrm{~mm}$ after 7 days at $25^{\circ} \mathrm{C}$. The surfaces were floccose, forming a thick mycelial mat at the center, white all over, later becoming dull green (25D3) due to the production of conidia. Conidia were very sparsely produced. The reverses of the colonies were brownish orange (5C4). Colonies on MEA (Malt Extract Agar) were $25 \mathrm{~mm}$ after 7 days at $25^{\circ} \mathrm{C}$. The surfaces were plane and floccose, forming a thick mycelial mat, white all over. The reverses of the colonies were greyish yellow (4B4). Conidia were sparsely produced. Ascomata were not produced during 7 days at $25^{\circ} \mathrm{C}$. Conidia germinated neither at $5^{\circ} \mathrm{C}$ nor on $\mathrm{G} 25 \mathrm{~N}(25 \%$ Glycerol Nitrate Agar). Colonies on CYA were $30 \mathrm{~mm}$ after 7 days at $37^{\circ} \mathrm{C}$. They were similar to those at $25^{\circ} \mathrm{C}$, except for forming more condensed mycelia. Cleistothecia were not produced during 7 days of incubation on either CYA or MEA. Cleistothecia could be produced with prolonged incubation, longer than one month. They were globose, $300 \sim 500 \mu \mathrm{m}$ in diameter, and pale yellow. The ascus were eight-spored, globose to subglobose, and $8 \mu \mathrm{m}$ in 
diameter. Ascospores were ellipsoid with a finely rough surface, and 3.5 4.5 $\mu \mathrm{m}$ in diameter. The anamorph, which was rarely observed, was Penicillium. Conidiophores were short, smooth-walled. Penicilli were mono-verticillate, and partly irregularly branched. Phialides were acicular with long necks, and $11 \sim 13 \times$ $1.5 \mu \mathrm{m}$. Conidia were ellipsoid, smooth-walled, and formed in chains on phialides. From the characteristics stated above, the present strain was identified as Talaromyces trachyspermus (Shear) Stolk and Samson.

\section{Isolation of Trachyspic Acid}

After the fermentation, an equivalent volume of acetone was added to 1.6 liters of culture broth obtained, and the mixture was filtered with the aid of Celite 545 (Johns Manville). The filtrate was adjusted to $\mathrm{pH} 2.0$ with $\mathrm{HCl}$, followed by two extractions, each with 2 liters of ethyl acetate. The extract was concentrated to $400 \mathrm{ml}$ under reduced pressure, and the concentrated organic layer was extracted twice, each time with $200 \mathrm{ml}$ of $50 \mathrm{~mm}$ $\mathrm{NaHCO}_{3}$ aqueous solution. The aqueous alkaline layer was adjusted to $\mathrm{pH} 2.0$, and then re-extracted with an equivalent volume of ethyl acetate. The extract was dried over anhydrous $\mathrm{Na}_{2} \mathrm{SO}_{4}$, and concentrated under reduced pressure to dryness. The residue $(2.8 \mathrm{~g})$ was applied on a Sephadex LH-20 column $(40 \times 430 \mathrm{~mm})$, and the column was developed with a mixture of EtOAc $\mathrm{CH}_{2} \mathrm{Cl}_{2}-\mathrm{MeOH}(9: 9: 1)$. The eluted fractions were assayed for the activity, and active fractions were pooled and concentrated. Trachyspic acid was finally purified with preparative HPLC (Senshu pak ODS H-5251 (Senshu Scientific Co., Ltd.), $20 \times 250 \mathrm{~mm}$, eluent; $60 \%$ $\mathrm{CH}_{3} \mathrm{CN}$ containing $0.1 \%$ trifluoroacetic acid, flow rate; $15 \mathrm{ml} /$ minute). A peak eluted from 7.8 to 10.2 minutes was collected, concentrated under reduced pressure, and lyophilized, to give $370 \mathrm{mg}$ of a hygroscopic powder. The obtained trachyspic acid showed a single peak on HPLC (Senshu pak ODS H-2151 (Senshu Scientific Co., Ltd.),
$6 \times 150 \mathrm{~mm}$, eluent; $55 \% \mathrm{CH}_{3} \mathrm{CN}$ containing $0.1 \%$ triffuoroacetic acid, flow rate; $1.5 \mathrm{ml} /$ minute, retention time; 7.5 minutes) and a single spot on TLC (silica gel plate (Merck Art. 5719), developed with $n$ - BuOH$\mathrm{AcOH}-\mathrm{H}_{2} \mathrm{O}(4: 2: 1)$, colored with hot $\mathrm{H}_{2} \mathrm{SO}_{4}$, Rf 0.59 ).

Physico-chemical Properties of Trachyspic Acid

Trachyspic acid (1) was obtained as a hygroscopic and acidic white powder. 1 was soluble in methanol, ethanol, ethyl acetate, chloroform, DMSO, and alkaline water. Based on the elementary analysis (Found: C 56.21, $\mathrm{H}$ 7.18, Calcd for $\mathrm{C}_{20} \mathrm{H}_{28} \mathrm{O}_{9} \cdot \mathrm{H}_{2} \mathrm{O}$ : C 55.81, $\mathrm{H}$ 7.02) and HR-FAB-MS (matrix: $m$-nitrobenzylalcohol, $\mathrm{QM}^{-}: m / z$ Found: 411.16505, Calcd: 411.16551), the molecular formula was established to be $\mathrm{C}_{20} \mathrm{H}_{28} \mathrm{O}_{9}$ (MW: 412). 1 showed $[\alpha]_{\mathrm{D}}^{25}+3.1^{\circ}(c 1.0, \mathrm{MeOH})$. The UV spectra showed maxima at $202 \mathrm{~nm}(\varepsilon 1,100)$ and $280(2,600)$ in $\mathrm{MeOH}$, and $205(5,000)$ and $284(1,900)$ in alkaline $\mathrm{MeOH}$. The IR spectrum $(\mathrm{KBr})$ showed the presence of carbonyl groups at $1723 \mathrm{~cm}^{-1}$ and a $\mathrm{C}=\mathrm{C}$ double bond at $1607 \mathrm{~cm}^{-1}$.

\section{Structural Elucidation of Trachyspic Acid}

Reaction of 1 with diazomethane afforded a trimethyl ester (2, $\mathrm{C}_{23} \mathrm{H}_{34} \mathrm{O}_{9}, \mathrm{MW}$ : 454). The IR spectrum of 2 did not show the presence of $\mathrm{OH}$ groups. Therefore, nine oxygen atoms consistent with the molecular formula of 1 were classified into three carboxylic, one ketone (198.1 ppm in the ${ }^{13} \mathrm{C}$ NMR spectrum), and two ether groups. The ${ }^{1} \mathrm{H}$ and ${ }^{13} \mathrm{C}$ NMR spectral data of 1 are summarized in Table 1.

The connectivity of proton and carbon atoms was confirmed with the ${ }^{1} \mathrm{H}^{-1}{ }^{13} \mathrm{C}$ COSY spectrum, as shown in Table 1. Analysis of the ${ }^{1} \mathrm{H}-{ }^{1} \mathrm{H}$ COSY spectrum revealed the presence of an $n$-nonyl group, an isolated olefinic methine, a geminally coupled isolated methylene, and an $\mathrm{ABX}$ proton spin system. ${ }^{1} \mathrm{H}^{-13} \mathrm{C}$ long range couplings of ${ }^{2} J$ and ${ }^{3} J$ observed in the COLOC

Fig. 1. Structures of trachyspic acid and its reduced products.
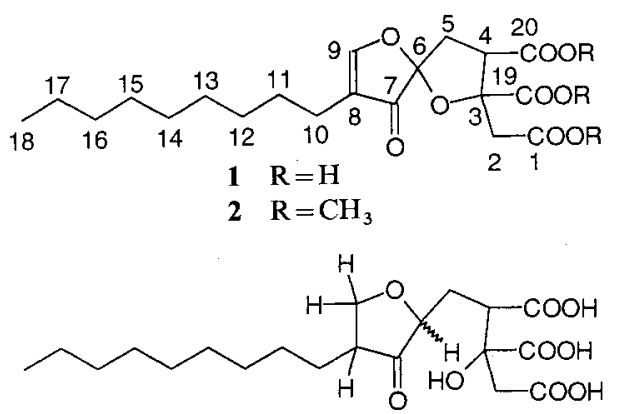

4,5 ( $\alpha$ or $\beta$ isomer)
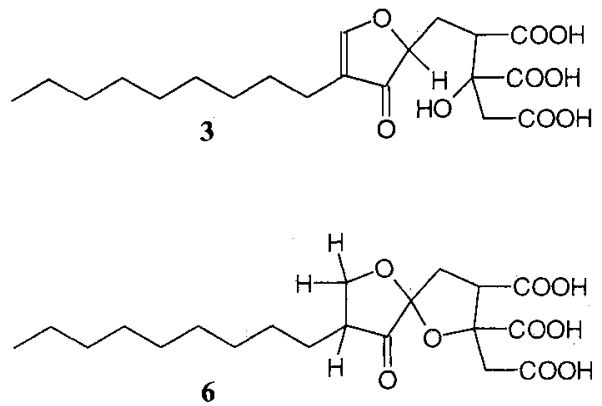
Table 1. NMR spectral data for $\mathbf{1}$ (trachyspic acid) and $\mathbf{5}$.

\begin{tabular}{|c|c|c|c|c|c|}
\hline \multicolumn{3}{|c|}{$1\left(\right.$ DMSO- $\left.d_{6}\right)$} & \multicolumn{3}{|r|}{$5\left(\mathrm{CD}_{3} \mathrm{OD}\right)$} \\
\hline Position & $\delta_{\mathrm{C}}$ & $\delta_{\mathrm{H}}$ (intensity, multiplicity, $J$ ) & Position & $\delta_{\mathrm{C}}$ & $\delta_{\mathbf{H}}$ (intensity, multiplicity, $J$ ) \\
\hline 1 & 170.0 & & 1 & $176.5^{\mathrm{b}}$ & \\
\hline 2 & 38.7 & $\begin{array}{l}2.72(1 \mathrm{H}, \mathrm{d}, J=16.8 \mathrm{~Hz}) \\
2.89(1 \mathrm{H}, \mathrm{d}, J=16.8 \mathrm{~Hz})\end{array}$ & 2 & 42.4 & $\begin{array}{l}2.74(1 \mathrm{H}, \mathrm{d}, J=16.7 \mathrm{~Hz}) \\
3.07(1 \mathrm{H}, \mathrm{d}, J=16.7 \mathrm{~Hz})\end{array}$ \\
\hline 3 & 86.5 & & 3 & 76.7 & \\
\hline 4 & 48.4 & $3.57(1 \mathrm{H}, \mathrm{dd}, J=7.7,12.0 \mathrm{~Hz})$ & 4 & 50.9 & $2.87(1 \mathrm{H}, \mathrm{dd}, J=2.3,12.2 \mathrm{~Hz})$ \\
\hline 5 & 37.4 & $2.38(2 \mathrm{H}, \mathrm{m})$ & 5 & 29.1 & $\begin{array}{l}1.61(1 \mathrm{H}, \mathrm{ddd}, J=2.3,10.2,14.0 \mathrm{~Hz}) \\
2.17(1 \mathrm{H}, \mathrm{ddd}, J=3.2,12.2,14.0 \mathrm{~Hz})\end{array}$ \\
\hline 6 & 108.0 & & 6 & 79.1 & $3.80(1 \mathrm{H}, \mathrm{dd}, J=3.2,10.2 \mathrm{~Hz})$ \\
\hline 7 & 198.1 & & 7 & 218.6 & \\
\hline 8 & 116.7 & & 8 & 47.8 & $2.49(1 \mathrm{H}, \mathrm{m})$ \\
\hline 9 & 174.3 & $8.45(1 \mathrm{H}, \mathrm{s})$ & 9 & 70.8 & $\begin{array}{l}3.86(1 \mathrm{H}, \mathrm{dd}, J=6.0,9.3 \mathrm{~Hz}) \\
4.24(1 \mathrm{H}, \mathrm{dd}, J=7.8,9.3 \mathrm{~Hz})\end{array}$ \\
\hline 10 & 20.4 & $2.04(1 \mathrm{H}, \mathrm{t}, J=7.5 \mathrm{~Hz})$ & 10 & 30.4 & $1.39(1 \mathrm{H}, \mathrm{m}), 1.65(1 \mathrm{H}, \mathrm{m})$ \\
\hline 11 & 27.4 & $1.40(2 \mathrm{H}, \mathrm{m})$ & 11 & 28.6 & c \\
\hline 12 & 28.5 & a & $\begin{array}{l}12,13 \\
14,15\end{array}$ & $\begin{array}{r}30.5,30.6 \\
30.7 \times 2\end{array}$ & $1.30(14 \mathrm{H}, \mathrm{br})^{\mathrm{c}}$ \\
\hline $\begin{array}{c}13,14 \\
15\end{array}$ & $28.6 \times 2,28.8$ & $1.26(12 \mathrm{H}, \mathrm{br})^{\mathrm{a}}$ & & & \\
\hline 16 & 31.2 & a & 16 & 33.1 & $\mathrm{c}$ \\
\hline 17 & 22.0 & a & 17 & 23.7 & $\mathrm{c}$ \\
\hline 18 & 13.8 & $0.86(3 \mathrm{H}, \mathrm{t}, J=6.8 \mathrm{~Hz})$ & 18 & 14.5 & $0.90(3 \mathrm{H}, \mathrm{t}, J=6.9 \mathrm{~Hz})$ \\
\hline 19 & 171.2 & & 19 & $173.9^{\mathrm{b}}$ & \\
\hline 20 & 170.5 & & 20 & 174.9 & \\
\hline
\end{tabular}

a The ${ }^{1} \mathrm{H}$ signals from $12-\mathrm{H}$ to $17-\mathrm{H}$ of 1 were observed as envelopes from $1.16 \mathrm{ppm}$ to $1.32 \mathrm{ppm}$ (total $12 \mathrm{H}$ ).

$b$ The assignments of $\mathrm{C}-1$ and $\mathrm{C}-19$ of 5 may be interchangeable.

c The ${ }^{1} \mathrm{H}$ signals from $11-\mathrm{H}$ to $17-\mathrm{H}$ of 5 were observed as envelopes from $1.24 \mathrm{ppm}$ to $1.41 \mathrm{ppm}$ (total $14 \mathrm{H}$ ).

Fig. 2. Informative ${ }^{1} \mathrm{H}^{13} \mathrm{C}$ long range couplings (arrows) and established partial structures of trachyspic acid (1).

(a) ${ }^{1} \mathrm{H}^{13} \mathrm{C}$ long range couplings obtained from the COLOC experiment. (b) ${ }^{1} \mathrm{H}^{-1}{ }^{13} \mathrm{C}$ long range couplings obtained from the $\mathrm{HMBC}$ experiment.

(a)

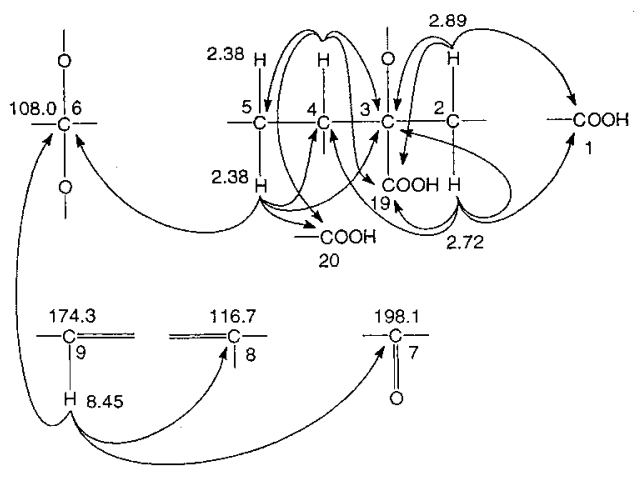

(b)

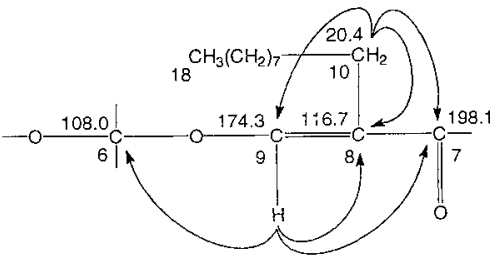

(correlation spectroscopy via long-range coupling) ${ }^{11)}$ spectrum are shown in Fig. 2a. Cross peaks from $5-\mathrm{H}$ to $\mathrm{C}-3, \mathrm{C}-4, \mathrm{C}-6$, and $\mathrm{C}-20$, and from $4-\mathrm{H}$ to $\mathrm{C}-3, \mathrm{C}-5$, $\mathrm{C}-19$, and $\mathrm{C}-20$, and from $2-\mathrm{H}$ to $\mathrm{C}-1, \mathrm{C}-3, \mathrm{C}-4$, and $\mathrm{C}-19$ suggested that three carboxylic groups were placed in a citric acid structure, although other connectivities (for example, from C-5 to C-20, and from C-4 to C-6) could not be excluded. Cross peaks from 9-H to C-6, C-7, and C-8, and the carbon chemical shifts of $\delta 108.0$, 198.1, 116.7, and 174.3 for C-6, C-7, C-8, and C-9, respectively, suggested the presence of a $\beta$-O-substituted $\alpha, \beta$-unsaturated ketone skeleton. The UV maximum at $280 \mathrm{~nm}$ also required this chromophore. This partial structure could be extended to an $\alpha-n$-nonyl- $\beta-O$ substituted $\alpha, \beta$-unsaturated ketone skeleton from additional ${ }^{1} \mathrm{H}-{ }^{13} \mathrm{C}$ long range couplings, from $10-\mathrm{H}$ to $\mathrm{C}-7$, $\mathrm{C}-8$, and C-9, observed in the HMBC (heteronuclear multiple bond correlation) ${ }^{12)}$ spectrum, as shown in Fig. 2b.

Catalytic reduction of 1 with $10 \% \mathrm{Pd}-\mathrm{C}$ in $\mathrm{MeOH}$ yielded four compounds $(\mathbf{3}, \mathbf{4}, 5$, and 6). The molecular formula of the main product (5) was ascertained to be 
Fig. 3. Informative ${ }^{1} \mathrm{H}^{13} \mathrm{C}$ long range couplings (arrows) obtained from the field gradient $\mathrm{HMBC}$ experiment on 5 (the assignment of $\mathrm{C}-1$ and $\mathrm{C}-19$ is interchangeable).

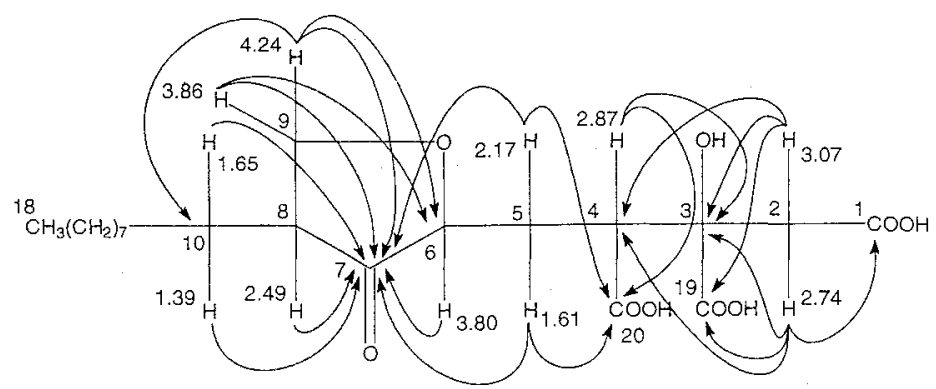

$\mathrm{C}_{20} \mathrm{H}_{32} \mathrm{O}_{9}$ (MW: 416), from FAB-MS. From this molecular formula, hydrogenation of 2 moles occurred in the reduction. The ${ }^{1} \mathrm{H}$ and ${ }^{13} \mathrm{C}$ NMR spectral data of 5 are summarized in Table 1. The UV maximum at $280 \mathrm{~nm}$ disappeared in $\mathbf{5}$, and the ketone carbon (C-7) was shifted to a lower field at $218.6 \mathrm{ppm}$, which indicated that the $\mathrm{C}=\mathrm{C}$ double bond of the $\alpha, \beta$-unsaturated ketone group was reduced. The olefinic methine proton (9-H) at $8.45 \mathrm{ppm}$ disappeared, and newly appeared $\mathrm{ABX}$ type of oxymethylene protons $(9-\mathrm{H})$ at 3.86 and 4.24 ppm was coupled with an X-proton $(8-\mathrm{H})$ at $2.49 \mathrm{ppm}$, which was further coupled with the $n$-nonyl protons. These observations confirmed the connectivity (Fig. 2b) between the $n$-nonyl group and the $\alpha, \beta$-unsaturated ketone group in $\mathbf{1}$. The ketal carbon (C-6) at $108.0 \mathrm{ppm}$ in 1 was changed to an oxymethine carbon at $79.1 \mathrm{ppm}$ in 5, indicating hydrogenolysis of an ether ring in the reduction. A newly appeared oxymethine proton $(6-\mathrm{H})$ at $3.80 \mathrm{ppm}$, occurring from the hydrogenolysis, was coupled with methylene protons $(5-\mathrm{H})$ at 1.61 and $2.17 \mathrm{ppm}$. Therefore, the linkage between C-5 and C-6 of 1 was established. Accordingly, the linkages between $\mathrm{C}-4$ and $\mathrm{C}-20$, and between $\mathrm{C}-1$ and $\mathrm{C}-2$, of 1 were now established with the cross peaks from $4-\mathrm{H}$ and $5-\mathrm{H}$ to $\mathrm{C}-20$, and from $2-\mathrm{H}$ to $\mathrm{C}-1$, respectively (Fig. 2a). Thus the citric acid skeleton of 1 was confirmed. The structure of 5 was finally established from ${ }^{1} \mathrm{H}^{-13} \mathrm{C}$ long range couplings observed in the field gradient HMBC spectrum,

Table 2. $\mathrm{IC}_{50}$ values of trachyspic acid and its reduced compounds for heparanase.

\begin{tabular}{cc}
\hline Compound & $\mathrm{IC}_{50}(\mu \mathrm{M})$ \\
\hline Trachyspic acid $(\mathbf{1})$ & 36 \\
$\mathbf{3}$ & 36 \\
$\mathbf{4}$ & 99 \\
$\mathbf{5}$ & 91 \\
$\mathbf{6}$ & 145 \\
\hline
\end{tabular}

as shown in Fig. 3. The linkage between $\mathrm{C}-6$ and $\mathrm{C}-7$ was established by cross peaks from $5-\mathrm{H}$ and $6-\mathrm{H}$ to $\mathrm{C}-7$. The linkage between $\mathrm{C}-7$ and C-8 was also confirmed by cross peaks from $8-\mathrm{H}, 9-\mathrm{H}$, and $10-\mathrm{H}$ to $\mathrm{C}-7$. The ether bond between $\mathrm{C}-6$ and $\mathrm{C}-9$ was supported by cross peaks from 9-H to C-6.

Based on the structure of reduction product $\mathbf{5}$, the structure of trachyspic acid was deduced as 1 (Fig. 1), since the remaining bond linkage of $\mathrm{C}-3$ to $\mathrm{C}-6$ via an oxygen was suggested by the molecular formula of $\mathbf{1}$. Trachyspic acid possesses a long alkyl ( $n$-nonyl) chain, an $\alpha, \beta$-unsaturated ketone, a spiroketal, and a polycarboxylic acid (citric acid skeleton) moiety.

Reduction product $\mathbf{4}$ showed the same molecular formula and a similar ${ }^{1} \mathrm{H}$ NMR spectrum to those of 5 . The coupling pattern between the oxymethine proton $(6-\mathrm{H})$ at $3.87 \mathrm{ppm}$ and the methylene protons $(5-\mathrm{H})$ at 1.82 and $2.07 \mathrm{ppm}$ of $\mathbf{4}$ was different from that of $\mathbf{5}$, and these proton signals were shifted from those of 5 . These observations suggested that 5 was the isomer of 4 at the C-6 position, occurring from the hydrogenolysis of the ether bond of 1 . Reduction product $3\left(\mathrm{C}_{20} \mathrm{H}_{30} \mathrm{O}_{9}, \mathrm{MW}\right.$ : 414), having the UV maximum at $280 \mathrm{~nm}$, showed a similar ${ }^{1} \mathrm{H}$ NMR spectrum to that of 5 , except the $\alpha, \beta$-unsaturated ketone moiety. An olefinic methine proton $(9-\mathrm{H})$ at $8.21 \mathrm{ppm}$ and an oxymethine proton (6-H) at $4.46 \mathrm{ppm}$ were observed. These observations indicated that only hydrogenolysis of the ether ring occurred in the reduction of $\mathbf{1}$ to 3 . Reduction product $6\left(\mathrm{C}_{20} \mathrm{H}_{30} \mathrm{O}_{9}, \mathrm{MW}: 414\right)$ showed no UV maxima at $280 \mathrm{~nm}$, and a similar ${ }^{1} \mathrm{H}$ NMR spectrum to that of 5 , except at the oxymethine $(6-\mathrm{H})$. These observations indicated that only the $\mathrm{C}=\mathrm{C}$ double bond of the $\alpha, \beta$-unsaturated ketone was reduced in $\mathbf{6}$.

\section{Biological Activity}

The $\mathrm{IC}_{50}$ values of trachyspic acid and its reduced 
compounds for heparanase are summarized in Table 2. Trachyspic acid inhibited heparanase in a dosedependent manner with an $\mathrm{IC}_{50}$ value of $36 \mu \mathrm{M}$ $(15 \mu \mathrm{g} / \mathrm{ml})$. On the other hand, trachyspic acid did not show any inhibitory activity towards bovine liver $\beta$-glucuronidase, at the concentration of $100 \mu \mathrm{g} / \mathrm{ml}$, suggesting its specificity to heparanase. Trachyspic acid has a hydrophobic and a hydrophilic moiety within the molecule. It should be noted, however, that the activity of trachyspic acid was not due to the detergent-like influence on the enzyme assay, as Triton X-100 did not affect the assay system, up to the concentration of $0.5 \%$.

The reduced compounds that lost the spiroketal or the $\mathrm{C}=\mathrm{C}$ double bond of the $\alpha, \beta$-unsaturated ketone also showed the inhibitory activities at the same concentration range. Citric acid, whose structure is contained in trachyspic acid, did not inhibit heparanase per se, up to the concentration of $1 \mathrm{~mm}$.

It has been reported that $T$. trachyspermus, originally described as Penicillium spiculisporum, produces decylcitric acid $^{13,14)}$ and spiculisporic acid. ${ }^{15)}$ They also have a long alkyl chain and a polycarboxylic acid moiety, but they have not been reported to have inhibitory activity against heparanase. Further study of the structureactivity relationship of these compounds on the inhibition of heparanase will be informative for the development of new inhibitors of heparanase.

\section{Acknowledgments}

The authors are grateful to Dr. Motowo NakAJIMA for invaluable information on preparation and assay procedure of heparansase.

\section{References}

1) Liotta, L. A.; P. S. Steeg \& W. G. Stetler-Stevenson: Cancer metastasis and angiogenesis: An imbalance of positive and negative regulation. Cell 64: $327 \sim 336,1991$

2) KARmer, R. H.; K. G. Vogel \& G. L. Nicolson: Solubilization and degradation of subendothelial matrix glycoproteins and proteoglycans by metastatic tumor cells. J. Biol. Chem. 257: 2678 2686, 1982

3) Nakajima, M.; T. Irimura, D. DI Ferrante, N. DI FERrante \& G. L. Nicolson: Heparan sulfate degradation: Relation to tumor invasive and metastatic properties of mouse B16 melanoma sublines. Science 220: $611 \sim 613,1983$

4) Vlodaysky, I;; G. KoRner, R. Ishai-MichaEli, P. Bashin, R. Bar-Shavit \& Z. Fuks: Extracellular matrix-resident growth factors and enzymes: Possible involvement in tumor metastasis and angiogenesis. Cancer Metastasis Rev. 9: 203 226, 1990

5) Irimura, T.; M. NAKAJIMA \& G. L. Nicolson: Chemically modified heparins as inhibitors of heparan sulfate specific endo- $\beta$-glucuronidase (heparanase) of metastatic tumor cells. Biochemistry 25: 5322 5328, 1986

6) SaIKI, I.; J. Murata, M. Nakajima, S. Tokura \& I. AzUma: Inhibition by sulfated chitin derivatives of invasion through extracellular matrix and enzymatic degradation by metastatic melanoma cells. Cancer Res. 50: $3631 \sim 3637,1990$

7) Nakajima, M.; A. DeChavigny, C. E. Johnson, J. Hamada, C. A. Stein \& G. L. Nicolson: Suramin: A potent inhibitor of melanoma heparanase and invasion. J. Biol. Chem. 266: $9661 \sim 9666,1991$

8) Nakajima, M.; T. Irimura \& G. L. Nicolson: A solid-phase substrate of heparanase: its application to assay of human melanoma for heparan sulfate degradative activity. Anal. Biochem. 157: 162 171, 1986

9) PitT, J. I.: The genus Penicillium and its teleomorphic states, Eupenicillium and Talaromyces. Academic Press. 1979

10) Kornerup, A. \& J. H. WANSCher: Methuen handbook of colour. Eyre Methuen, London. 1978

11) Kessler, H.; C. Griesinger, J. Zarbock \& H. R. LoOSLI: Assignment of carbonyl carbons and sequence analysis in peptides by heteronuclear shift correlation via small coupling constants with broadband decoupling in $t_{1}$ (COLOC). J. Magn. Res. 57: $331 \sim 336,1984$

12) BAX, A. \& M. F. Summers: ${ }^{1} \mathrm{H}$ and ${ }^{13} \mathrm{C}$ assignment from sensitivity-enhanced detection of heteronuclear multiplebond connectivity by 2D multiple quantum NMR. J. Am. Chem. Soc. 108: $2093 \sim 2094,1986$

13) Gatenbeck, S. \& A. MÅHLÉN: A metabolic variation in Penicillium spiculisporum Lehman. I. Production of (+)- and (-)-dectylcitric acids. Acta Chem. Scan. 22: 2613 2616, 1968

14) Brandänge, S.; S. Josephson, A. MÅhlén, L. Mörch \& S. VALLÉN: (-)-Decylcitric acid and (+)-isocitric acid as metabolites from Penicillium spiculisporum-a correction. Acta Chem. Scan. B30: $177 \sim 187,1976$

15) Clutterbuck, P. W.; H. Raistrick \& M. L. Rintoul: Studies in the biochemistry of micro-organisms. Part XVI. On the production from glucose by Penicillium spiculisporum Lehman of a new polybasic fatty acid, $\mathrm{C}_{17} \mathrm{H}_{28} \mathrm{O}_{6}$ (the lactone of $\gamma$-hydroxy- $\beta \delta$-dicarboxypentadecoic acid). Trans. Roy. Soc., B220: $301 \sim 330,1931$ 